\title{
Pengelolaan arsip di detik Sumatera Selatan
}

\section{Reni Mustika, Aprillian Chairunesa, Desti Dwi Putri, dan Eksi \\ Pratama}

\section{Abstract}

This article discusses how to manage archives in Seconds South Sumatra, therefore the processing of archives is needed. The archive processing in this secs does not have a special unit in processing because the archive is managed under the editorial secretary, for the storage of the archive in South Sumatra is kept by date on the issuance of the archive and the archive in Seconds of South Sumatra is stored in Data Base and Manual Print. The obstacles faced by Seconds South Sumatra in managing the archive of human resources that are not educational background archives, so in penglolaannya less adequate.

Keywords: archive management, mass media archive

\section{Pendahuluan}

\section{Latar Belakang Masalah}

Seperti yang kita ketahui, sebuah informasi menjadi kebutuhan semua orang, oleh karena itu dalam sebuah informasi sangat penting dan berguna. Dalam kehidupan sehari-hari kita membutuhkan kegiatan organisasi yang pada dasarnya membutuhkan informasi.

Salah satu sumber informasi yang di butuhkan dalam menunjang proses kegiatan administrasi maupun birokrasi adalah arsip (record). Sebagai rekaman informasi dari seluruh aktivitas organisasi, arsip berfungsi sebagai pusat ingatan, alat bantu pengambilan keputusan, bukti eksistensi organisasi dan untuk kepentingan organisasi lain. Berdasarkan fungsi arsip yang sangat penting tersebut maka harus ada manajemen atau pengelolahan arsip yang baik sejak penciptaan sampai dengan penyusutan. 
The memory of participants in historic events provides testimony that can be used to test and either corroborate or correct collective memory. ${ }^{1}$

Arsip adalah gudang memori, menyediakan bukti yang dapat diandalkan untuk memeriksa masa lalu. Jadi maksudnya disni bahwa arsip merupakan gudang atau tempat ingatan mengenai masa lalu. Bahwasannya arisp itu merupakan sebuah bukti yang harus dijadikan memori untuk memerikasa keadaan dimasa yang akan dating.

Arsip merupakan rekaman kegiatan atau persitiwa dalam berbagai jenis bentuk dan dan media sesuai dengan perkembangan teknologi dan informasi dan komunikasi yang dibuat oleh lembaga pendidikan, perusahaan, organisasi, kemasyrakatan dan perseorangan dalam kegiatan kehidupan bermasyrakat, berbangsa dan bernegara. ${ }^{2}$ Disini dikatakan bahwa sebuah arsip tersebut merupakan sebuha rekeman kegiatan atau peristiwa yang dibuat menjadi berbagai macam bentuk dan media yang dibuat oleh berbagai lembaga, perusahaan dan organisasi baik masyarakat maupun perorangan dalam kehidupan berbangsa.

Arsip sangat berperan penting dalam berbagai kegiatan administrasi, dalam kehidupan sehari-hari dan dalam berbagai bidang kegiatan. Arsip juga dapat dikatakan sebgai pusat ingatan serta sejarah dan sebagai barang bukti serta sebagai informasi baik untuk pribadi maupun masyrakat. Maka dari itu, sebuah organisasi maupun sebuah lembaga tidak terlepas dari yang namanya arips, karena arsip merupakan sebuah rekaman kegiatan atau sebuah catatan penting baik itu tertulis maupun maupun terekam dalam beerbagai bentuk media.

\footnotetext{
${ }^{1}$ Rendall C. fimerson. International digital libraryperspectives vol. 19, No. 3. Archives and Memory. H, 89. Diakses tanggal 1 Juni 2018 di journal emerald

${ }^{2}$ Undang-undang Republik Indonesia, No 43 tahun 2009 tentang kearsipan
} 
Jika dilihat dari fungsinya arsip dapat dibekakan menjadi dua yaitu arsip dinamis dan arsip statis. Arsip dinamis merupakan sebuah arsip yang masih digunakan dalam kegiatan sehari-sehari yang digunakan sacara langsung dalam proses kegiatan administrasi. Sedangkan arsip statis itu merupakan sebuah arsip yang masih digunakan secara terus menerus, bagi kelangsungan hidup suatu instansi. ${ }^{3}$ Antara arsip dinamis dan statis sebenarnya sama saja memiliki fungsi sebagai penunjang dan memenuhi kebutuhan suatu organisasi atau instansi tersebut.

Agar arsip dapat berperan sebagaimana fungsinya perlu dikelola dengan baik dan benar artinya ditata secara sistematis sehingga jika sewaktu-waktu diperlukan dapat dengan cepat dan tepat dan lengkap disajikan. Dalam pengelolaan arsip, termasuk di dalamnya adalah upaya memelihara arsip baik dari segi fisik maupun kerusakan. Sedangkan memelihara dari segi informasi yaitu tidak terjadinya kebocoran informasi. Sedangkan keadaan yang sesunggguhnya arsip di Detik Sumsel arsip tersebut belum dikelola secara maksimal sehingga jika di butuhkan sewaktuwaktu arsip tersebut sangat sulit ditemukan.

Oleh sebab itu sistem kearsipan yang baik adalah sistem yang mudah dilaksanakan praktis dan ekonomis, mudah dimengerti, tidak memakan tempat dan sesuai bagi organisasi (perusahaan) yang bersangkutan. Sebagaimana yang kita ketahui bahwa setiap kegiatan baik individu maupun organisasi akan menghasilkan sebuah arsip, terutama pada lembaga yang bergerak dalam bidang penyediaan informasi seperti surat kabar.

Detik Sumsel adalah portal yang menyediakan berita dan informasi Sumsel, nasional, \& internasional dengan mengutamakan kecepatan serta kedalaman. Media online ini diperbaharui selama 24 jam dalam sepekan, \& secara kreatif

3 Sedarmayanti. Tata Kearsipan dengan Memanfaatkan Teknologi Modern. Mandar Maju: Bandung, 2008. Hlm,33 
menampilkan teks dan foto. Oleh karena itu arsip pada Detik Sumsel haruslah dikelola secara baik \& professional agar masyarakat dapat mengakses berbagai jenis informasi seputar Sumsel dari berbagai macam kriteria, baik berdasarkan topik pembahasan maupun berdasarkan waktu saat berita tersebut diterbitkan.

Dari berbagai penjelasan diatas maka dari itu observasi ini dilakukan untuk mengetahui bagaimana sistem pengloaan arsip, apasaja kendala yang di hadapi dalam penglolaan arsip, dan bagaimana posisi unit kearsipan yang ada di Detik Sumsel.

\section{Rumusan Masalah}

1. Bagaimana sistem penglolaan Arsip di Detik Sumsel

2. Apa saja kendala dalam penglolaan Arsip di Detik Sumsel?

3. Bagaimana posisi keberadaan untuk pengelohan Arsip secara struktural di Detik Sumsel?

\section{Pembahasan}

\section{a. Pengertian Arsip dan Kearsipan}

Arsip berasal dari kata dasar 'archive' berarti permulaan yang berkembang menjadi beberapa karta seperti Archaios, Archeion dan Archivum. Istilah 'archief' (bahasa Belanda), mempunyai arti dokumen yang diciptakan atau diperlihara, tempat/gedung untuk menyimpan/memlihara, lembaga yang bertanggung jawab terhadap proses pemliharaan arsip. ${ }^{4}$ Disini maksudnya arsip itu merupakan sebuah dokumen yang diperlihara atau disimpan disebuah gedung yang dipertanggung jawabkan oleh sebuah lembaga dalam pemeliharaan arsip tersebut.

Pengertian arsip bukan berarti hanya kertas saja, tetapi dapat berarti naskah, buku foto, film, rekaman suara, gambar,

${ }^{4}$ Susiasih Damalita. Jurnal Ekonomi vol. 3, No. 1, 2009. Pentingnya Manajemen Arsip di Lingkungan Perguruan Tinggi. H.3 diakses pada tanggal 1 mei 2018 
peta gambar bagan dan dokumen-dokumen lain dalam segala macam bentuk dan sifatnya, asli atau salinan serta dengan segala macam penciptaannya dan yang di hasilakn atau diterima oleh suatu organisasi atau badan, sebagai bukti dari tujuan organisasi atau kaarrena pentingnya organisasi yang terkandung didalamnya. ${ }^{5}$

Sedangkan menurut Basir Barthos arsip adalah setiap catatan tertulis baik dalam bentuk gambar ataupun bagan yang memuat keterangan-keterangan mengenai sesuatu subyek (pokok persoalaan) ataupun peristiwa yang dibuat orang untuk membantu daya ingat orang itu pula. ${ }^{6}$ Disini dimaksudkan bahwa arsip tersebut merupakan sebuah catatan yang tertulis yang dibuat dalam bentuk gambar ataupun bagan yang memiliki keterangan-keterangan mengenai suatu subyek maupun peristiwa yang dapat membantu daya ingat orang.

Dari segi fungsinya arsip itu terbagi menjadi dua yaitu arsip dinamis dan arsip statis. Arsip dinamis merupakan arsip yang masih digunakan dalam kegiatan sehari-hari. Sedangkan arsip statis merupakan arsip yang tidak digunakan secara langsung dalam proses perencanaan, penyelengaraan kehidupan berbangsa pada umumnya maupun untuk penyelenggaran sehari-hari administrasi negara. ${ }^{7}$

Arsip dalam dalam organisasi harusnya dapat mebedakan antara arsip dinamis dan arsip statis agar tidak terjadi kesalahan dalam penggunaanya. Dalam penglolaan arsip di Detik Sumsel tidak disebutkan pembedaan antara arsip dinamis dan arsip statis. Terdapat persamaan dalam proses pengarsipan yang ada di Detik Sumsel, dengan hal ini kita dapat melihat bahwa tidak adanya pembeda antara kedua fungsi arsip tersebut.

\footnotetext{
${ }^{5}$ Jumiyati, Emi. Pusat Teknologi Bahan-bahan Nuklir no vol.2, No. 03, 2009. Penglolaan Arsip di Pusat Teknologi Bahan-bahan Nuklir. H.56 diakses tanggal 1 mei 2018

${ }^{6}$ Basir Brathos. Manajmen Kearsipan. Jakarta : Bumi Aksara

${ }^{7}$ Sulisttyo Basuki. Pengantar Ilmu Kearsipan. Jakarta : Universitas terbuka. 2015. H, 1.4
} 
Kearsipan ini mempunyai peranan sebagai pusat ingatan, sebagai sumber informasi dan sebagai alat pengawasan yang sangat di perlukan dalam setiap organisasi dalam rangka kegiatan perencanaan, pengembangan, perumusan kebijaksanaan, pengambilan keputusan, pembuatan laporan, pertanggung jawaban, penilaian dan pengendalian setepat-tepatnya. Setiap kegiatan tersebut, baik dalam organisasi pemerintah maupun swasta selalu ada kaitannya dengan masalah arsip. Arsip mempunyai peran penting dalam proses penyajian informasi bagi pimpinan untuk membuat keputusan dan merumaskan kebijakan, oleh sebab itu untuk dapat menyajikan informasi yang lengkap, cepat dan benar haruslah ada sistem dan prosedur kerja yang baik di bidang kearsipan. ${ }^{8}$ Arsip sangatlah berperan penting dalam berbagai kegiatan apalagi dalam proses penyajian informasi, karena penyajian informasi ini sangat berperan pentinda dalam pengambilan keputusan, dan merumuskan kebijakan dalam sebuah organisasi, seperti halnya di sebuah media massa Detik Sumsel, penyajian informasi yang dilakukan di Detik Sumsel tersebut dilakauakan sangat baik dan rapi karena arsip-arsip yang ada di Detik Sumsel itu sudah dikelola di dalam sebuah media elektronik dan online. Jadi dalam penyajian informasinya Detik Sumsel sudah tertata sangat baik dan rapi.

\section{b. Penglolaan Kearsipan}

Menurut Wursanto penglolaan arsip adalah kegiatan yang berubungan dengan penerimaan warkat, penyimpanan, pengiriman, pencatatan, penyingkiran atau penyusutan, dan pemusnahan warkat. $^{9}$ jadi dalam kegiatan penglolaan arsip tersebut sangatlah berhubungan denganpenerimaan, penyimpanan, pengiriman, pencatatan, penyusustan serta pemusnahan.

8 Ermawaty. Jurnal Tabularasa PPS UNIMED Vol.10, No.2.,2013. Penglolaan Manajmen Kearsipan di Perguruan Tinggi. h.142 diakses 1 mei 2018

${ }^{9}$ Wursanto. Kearsipan 1. Yogyakarta: Kanisius. 2003 h.16 
The very term 'archiving' contains the implication that the documents held in the archive are old and lagerly or completely irrelevant: documents held because they ought to be held rather then because they have anything to do information provider. 10

Istilah 'pengarsipan' mengandung implikasi bahwa dokumen yang disimpan sebagai arsip lama dan sebagaian besar tidak relevan : karena dokumen yang disimpan harus diadakan setiap hari karena berkaitan sebagai penyedia informasi.

Jadi maksudnya disini bahwa pengarsipan itu mempunyai dampak bagi dokumen yang disimpan menjadi arsip karena sebgaian tidak relevan jadi arsip itu harus dilakuakan sistem pengarispan setiap saat untuk menjaga jika suatu saat arsip itu dibutuhkan dalam kegiatan sehari-hari. Dengan adanya sistem pengarsipan sebuah arsip akan lebih terjaga atau terawatt untuk penyediaan informasi baik untuk saat ini ataupun masa yang akan dating.

Sedangkan menurut Serdamayanti pengarsipan itu memiliki tujuan yaitu ${ }^{11}$ :

1. Menghimpun informasi

2. Mencatat dan mengklasifikasikan informasi

3. Mengintrepretasikan informasi

4. Mengolah informasi

5. Untuk akuntabilitas dan auditing

6. Menyimpan dan mengambil kembali informasi dari tempat penyimpanan, mendistribusikan informasi

7. Ketetapan penggunaan informasi

Dalam tata kearsipan suatu proses kegiatan penglolaan arsip dengan lingkup kegiatan keseluruhan siklus daur hidup

\footnotetext{
${ }^{10}$ Jon Helfet. Focus Article Vol. 14 No. 3. The use of recoddable CDROMs as an electronic archiving medium for librarians. H, 222. Diakses tanggal 1 juni 2018 di jurnal emerald.

${ }^{11}$ Sanora, Neny Anindya. E-journal Administrasi Negara Vol. 4, No. 2, 2016. Penglolaan Arsip pada Bagian Tata Usaha Biro Umum Kantor Gubernur Provinsi Kalimantan Timur. H, 4045 diakses 1 mei 2018
} 
arsip mulai dari tahapan penciptaan, penataan penggunaan, penemuan kembali penyimpanan sampai dengan penyusustan. ${ }^{12}$

1. Penciptaan Arsip

Penciptaan arsip merupakan awal dari lahirnya suatu arsip dan menentukan apakah suatu informasi akan menjadi arsip atau tidak. Jika informasi tersebut menjadi arsip maka informasi tersebut akan dilakukan penataan dan apabila informasi tersebut tidak menjadi arsip maka akan di lakukan pemusnahan.

2. Penataan Arsip

Penataan arsip bertujuan untuk mengatur dan menyimpan informasi dan fisik arsip secara sistematis dan logis agar dapat ditemukan dengan cepat dan tepat, serta menunjang terlaksananya penyusustan arsip yang berdaya guna dan berhasil guna.

3. Penggunaan Arsip

Arsip memegang peran penting karena arsip merupakandasar bagi pemimpin untuk pengambilan keputusan di dalam menentukan kebijaksanaan.

4. Penemuan kembali

Penglolaan arsip yang baik dan benar akan mempermudah menemukan kembali arsip yang diperlukan dan tidak memakan waktu yang terlalu lama.

5. Penyimpanan Arsip

Penyimpanan dan penemuan arsip dengan cepat dan tepat merupakan tujuan dari penataan arsip. Setiap pegawai akan merasa tertunda menyelesaikan pekerjaannya apabila ada arsip yang di buuthkan belum dapat ditemukan kembali pada waktu yang diperlukan. Menyimpan arsip pada tempat yang teratur, belum tentu dapat menjamin arsip termaksud dapat ditemukan kembali dengan mudah pula. Penemuan kembali arsip sangat erat pula dengan sistem penataan atau penyimpanan yang

${ }^{12}$ Jumiyati, Emi, op.cit. hlm 58 
dipergunakan, serta tergantung dari kedekataan petugas arsip. Oleh karena itu perlu diperkirakan tentang penentuan pemilihan sistem penataan dan penyimpanan arsip yang sesuai dengan kebutuhan. Dalam penyimpanan arsip terdapat enam sistem penyimpanan arsip yang bisa diguanakan dalam pengelolaan arsip yaitu:

a. Sistem penyimpanan arsip berdasarkan nomor adalah salah satu sistem penataan berkas berdasarkan kelompok permasalahan yang kemudian masing-masing atau setiap masalah diberi nomer tertentu.

b. Sistem penyimpanan arsip berdasarkan abjad adalah salah satu sistem penataan berkas yang umulmnya dipergunakan untuk menata berkas yang beraturan dari A sampai $Z$ dengan berpedoman pada peraturan mengindeks.

c. Sistem penyimpanan arsipberdasarkan pokok masalah adalah sistem penataan berkas berdasarkan kegiatankegiatan yang berkenaan dengan masalah-masalah yang berhubungan dengan perusahaan yang menggunakan sistem ini.

d. Sistem penyimpanan arsip berdasarkan lokasi/wilayah adalah sistem penataan berkas berdasarkan tempat (lokasi), daerah atau wilayah tertentu.

e. Sistem penyimpanan arsip berdasarkan tanggal, baik tanggal terima arsip atau tanggal di buatnya arsip tersebut, adalah sisitem penataan berkas berdasarkan urutan tanggal, bulan dan tahun yang mana pada umumnya tanggal yang dijadikan pedoman adalah tanggal surat.

6. Penyusutan Arsip

Tujuan penyusutan arsip adalah mengendalikan arsip yang tercipta secara terencana dan menyelamatkan arsip sebagai bahan bukti pertanggungjawaban nasional, serta mengehemat biaya untuk keperluan ruangan, peralatan pemloharaan dan tenaga.

\section{Gambaran Umum Daerah Penelitian}


Detik Sumsel adalah portal yang menyediakan berita dan informasi sumsel, nasional, dan internasional dengan menggunakan kecepatan serta kedalaman. Media online ini diperbarui selama 24 jam dalam sepekan, dan secara kreatif menampilkan teks dan foto.

Secara legalitas, Detik Sumsel berbadan hukum dibawah PT. Numa Global Media dengan Akte Notaris Tutwuri Handayani SH MKn, SK Menkumham NO.AHU-511.AH.02.01 Tertanggal 26 Desember 2012. Tapi mulai dikelola secara propesional dan go public sejak 19 januari 2016

\section{Hasil Penelitian Dan Pembahasan}

Berdasarkan hasil wawancara dan observasi yang dilakukan secara intensif di Detik Sumsel dalam pengelolaan arsip seperti yang dijelaskan oleh pengelola arsip terdiri dari lima hal yaitu meliputi pencatatan arsip, penyimpanan arsip, pemeliharaan arsip, pemindahan arsip, dan pemusnahan arsip. Dalam pengelolaan arsip ini sesuai dengan pernyataan visi dan misi perlu diperhatikan dengan proses ini. Dalam pengumpulan data disini kami memperoleh data mealaui wawancara dengan Kepala Detik Sumsel mengenai arsip-arsip dan data yang ingin kami teliti.

\section{Pembahasan}

Berdasarkan penelitian yang telah dilakukan oleh penulis mengenai penglolaan arsip mencakup posisi kearsipan, pencatatan arsip, penyimpanan arsip, pemeliharaan arsip, pemindahan arsip dan pemusnahan arsip.

a. Posisi kearsipan atau unit penglola kearsipan

Unit penglola arsip merupakan satuan kerja pada penciptaan sebuah arsip yang memiliki tugas dan tanggung jawab untuk mengolah arsip yang berkaitan dengan penciptaan arsip dilingkungannya. ${ }^{13}$ Bahwasannya unit pengolahan arsip ini

\footnotetext{
${ }^{13}$ Undang-undang No. 43 tahun 2009 pasal 1 angka 20 tentang kearsipan
} 
bertujuan untuk mengolah semua arsip yang berkaiatan dengan arsip yang dilingkungannya. Dengan adanya unit kearsipan ini proses pengolahan arsip sangat tertata dan terarah. Tetapi lain halnya dengan pengolahan arsip di Detik Sumsel. Di Detik Sumsel pengolahan arsipnya tidak memiliki posisi khusus dalam pengolahannya tetapi dalam proses pengolahan arsip Detik Sumsel berada di bawah Sekertaris Redaksi.

b. Penciptaan kearsipan

Dari data yang kami dapatkan penciptaan arsip terbagi menjadi dua penciptaan yaitu.

1. Intern

Intern ini arsip yang dibuat sendiri oleh lingkungan dalam perusahaan, meliputi standar berita, bentuk berita, formulir berita dan sebagainya. arsip intern pada Detik Sumsel ini merupakan data-data tentang kegiatan yang dilakuakan Detik Sumsel dalam kegiatan organisasinya, misalnya data mengenai berdirinya detik sumsel, data mengenai karyawan, serta data-data lainnya.

2. Ekstern

Ekstern ialah arsip arsip yang diterima oleh pihak lain dan bukan dari dalam perusahaan, bisa perorangan atau perusahaan pembuatan berita tidak dapat dikontrol dan dikendali perusahaan sehinggah berita yang diterima suatu perusahaan berbeda satu dengan yang lainya. Di Detik Sumsel penciptaan arsip ektren ini di dapatkan dari data-data dari luar kegiatan organisasinya. Misalnya surat masuk, berita yang dikirimkan dari pihak luar dan lain sebagainya.

3. Penataan kearsipan

Bedasarkan data dan hasil observasi, Penataan arsip di Detik Sumsel ditata dalam sebuah database yang disusun berdasarkan tanggal diterbitkanya berita tersebut. Database ini akan secara otomatis menyimpan setiap arsip yang diuplod pada hari tersebut dan pada tanggal tersebut.

4. Penggunaan kearsipan 
Dalam hal penggunaan arsip di Detik Sumsel, arsip ini digunakan oleh semua orang yang membutuhkan arsip tersebut atau orang yang memerlukan arsip tersebut untuk kepentingan pribadi atau organisasi. Maksudnya disini arsip di Detik Sumsel bisa digunakan oleh semua orang yang membutuhkan arsip tersebut karena arsip di Detik Sumsel ini sudah dionlainekan dan bisa di akses melalui sebuah web atau aplikasi. Tetapi tidak semua arsip di Detik Sumsel bisa diakses oleh semua pengguna, pengguna hanya bisa mengakses arsip ekstern saja karena arsip ektren ini sudah diuplod.

5. Penemuan Kembali

Penemuan kembali arsip di Detik Sumsel sangat sedrhana dan sangat mudah, jika para pencari informasi ingin menemukan arsip yang berkaitan dengan apa yang dia inginkan, para pencari informasi tidak perlu susah-susah menemuai seseorang yang mengelola arsip tersebut. Mereka cukup membuka website yang telah disediakan, kemudian memasukkan keyword atau kata kunci yang ingin dicari.

6. Penyimpanan Arsip

Dari hasil observasi ditemukan bahwa arsip yang ada di Detik sumsel dalam penglolaannya tidak tersitematis, maksud dari tidak tersistematis ini, sistem pengelolahanya di lakukan berdasarkan berita yang di terbitkan. Jadi arsip ini tidak di kelola berdasarkan tahun terbit ataupun berabjad. untuk melihat lebih jelasnya bisa kita lihat di www.detiksumsel.com atau bisa download di playstore Detiksumsel.

Di Detik Sumsel ini banyak pilihan tentang berita dari kota sampai kedaerah, beritanya bisa kita lihat secara detail, berita ini juga beurutan dengan aturan yang dibuat oleh detik sumsel seperti: 
1. Ekonomi

Berita dalam bentuk ekonomi menjelaskan tentang keadaan masyarakat yang di berbagai daerah maupun sesumatera selatan. Dengan adanya bentuk berita seperti agar para kalangan masyarakar mudah menemukannya

2. Politik

Bertita dalam bentuk politik ini menjelaskan tentang beritaberita politik seperti demo, adanya rapat kerja tentang partai, kampanye dan lain-lain.

3. Kriminal

Berita dalam bentuk kriminal ini menjelaskan tentang krimnal yang ada didaerah setempat. Seperti pembegalan, pembunuhan dan lain-lain.

4. Olahraga

Berdasarkan bentuk berita diatas, olahraga ini banyak sekali digemari oleh masyarakat karena berita ini banyak bahkan tidak didetik sumsel saja semua siaran chanel televisipun menyampai berita olahraga

5. Pendidikan

Dalam berita pendidikan ini biasanya menyapaikan tentang sekolah dan dunia mahasiswa maupun bentuk umum.

6. Nasional

Nasional kata ini mencakup semua berita tentang sesumatera dan berita penting.

Serta penyimpanan arsip di Detik Sumsel ini memiliki dua cara penyimpanan yaitu:

a. Database

Penyimpanan database ini dilakukan secara online dan sismtematis didalam sebuah komputer yang penyimpananya disusun berdasarkan berita yang di terbitkan atau sesuai dengan tanggal diterbitkannya berita tersebut.

b. Sistem manual print 
Penyimpanan manual print ini selain dia tersimpan di media online, beritanya juga bisa di printkan (tercetak), sistem penyimpanan ini sebagai bukti untuk kearsipan yang digunakan sewaktu-waktu dan dibutuhkan juga sebagai informasi tercetak.

7. Penyusutan kearsipan

Dari hasil wawancara dan observasi kami, Detik sumsel belum dilalukanya penyusutan arsip dikarena detik sumsel ini merupakan portal yang menyediakan informasi online yang baru.

\section{Kendala-kendala Penglolaan Arsip di Detik Sumsel}

Berdasarkan hasil wawancara ditemukan bahwa faktor kendala penglolaan arsip di Detik Sumsel ialah sumber daya manusianya karena sumber daya manusia yang mengelola arsip di Detik Sumsel ini bukan seorang arsiparis atau yang berlatarbelakang pendidikan dari jurusan arsip melainkan berlatar belakang pendidikan ilmu lain sehingga dalam penglolaan arsipnya mereka tidak mengetahui manakah arsip yang penting dan manakah arsip yang tidak penting.

\section{Struktural Arsip di Detik Sumsel}

Struktur organisasi adalah suatu kerangka yang menunjukan semua tugas untuk mencapai tujuan tertentu, struktur oraganisasi juga diperlukan untuk memberi wadah bagi tujuan, misi, tugas pokok dan fungsi. Namun Penglolaan arsip di Detik Sumsel ini tidak memiliki unit khusus untuk melakukan penglolaan arsipnya. Penglolaan asip di Detik Sumsel ini di bawah Sekertaris Redaksi yang ada di Detik Sumsel.

\section{Kesimpulan}

Berdasarkan observasi dan uraian yang telah penulis kemukakan pada bab-bab sebelumnya bahwa penglolaan arsip di Detik Sumsel ini tidak memiliki unit khusus dalam pengelolaanya karena pengelolaan arsip ini di bawah Sekertaris Redaksi, dalam penyimpananya arsip di Detik Sumsel ini di simpan berdasarkan tanggal di terbitkannya arsip tersebut dan arsip di Detik Sumsel di 
simpan di Data Base dan Manual Print. Dalam penemuan kembali arsip di Detik Sumsel pencari informasi bisa dilakukan secara langsung dengan membuka website dari Detik Sumsel.

Kendala yang di hadapi oleh Detik Sumsel dalam melakukan penglolaan arsip yaitu sumber daya manusianya yang bukan berlatar belakang pendidikan arsip, sehingga dalam penglolaannya kurang memadai.

Untuk posisi kearsipan yang ada didetik sumsel sudah dikatakan cukup baik karena arsip yang ada didetik sumsel tersimpan secara database dan manual print dari kedua penyimpan tersebut memiliki fungsi yang berbeda, untuk penyimpanan database itu tersimpan dalam bentuk elektronik sedangkan manual print berbentuk tercetak namun bentuk ini jarang digunakan, karena manual sebagai bukti sewaktu-waktu arsip tersebut dibutuhkan.

\section{Daftar Pustaka}

Basir Brathos. (2009). Manajmen Kearsipan. Jakarta: Bumi Aksara Ermawaty. (2013). Jurnal Tabularasa PPS UNIMED Vol.10, No.2. Penglolaan Manajmen Kearsipan di Perguruan Tinggi. diakses tanggal 1 Mei 2018

Jon Helfet. (1996). Focus Article Vol. 14, No. 3. The use of recordable CDROMs as an electronic archiving medium for librarians. Diakses tanggal 1 Juni 2018 dijurnal Emerald.

Jumiyati, Emi. (2009). Jurnal Batan no vol.2, No. 03. Penglolaan Arsip di Pusat Teknologi Bahan-bahan Nuklir. Diakses tanggal 1 Mei 2018 di Jurnal Batan

Rendall C. fimerson. International digital library perspectives vol. 19, No. 3. Archives and Memory. Diakses tanggal 1 Juni 2018 dijurnal Emerald.

Sanora, Neny Anindya. (2016). E-journal Administrasi Negara Vol. 4, No. 2. Penglolaan Arsip pada Bagian Tata Usaha Biro Umum Kantor Gubernur Provinsi Kalimantan Timur. Diakses tanggal 1 Mei 2018

Sedarmayanti. (2008). Tata Kearsipan dengan Memanfaatkan Teknologi Modern. Bandung : Mandar Maju.

Sulistyo Basuki. (2015). Pengantar Ilmu Kearsipan. Jakarta: Universitas Terbuka

Susiasih Damalita. (2009). Jurnal Ekonomi vol. 3, No. 1. Pentingnya Manajemen Arsip di Lingkungan Perguruan Tinggi. diakses tanggal 1 Mei 2018 
Undang-undang No. 43 tahun 2009 tentang kearsipan

Undang-undang No. 43 tahun 2009 pasal 1 No. 20 tentang kearsipan

Wursanto. (2003). Kearsipan 1. Yogyakarta: Kanisius. 